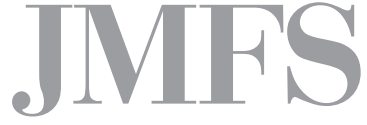

Journal of Management and Financial Sciences
Volume XI

Issue 32 (June 2018)

pp. 83-102

Warsaw School of Economics

Collegium of Management and Finance

Andrzej Jędruchniewicz

Department of Economics and Economic Policy

Warsaw University of Life Sciences-SGGW

\title{
Changes in Wages and Cyclical Fluctuations in Lithuania in View of the Austrian School of Economics
}

\footnotetext{
ABSTRACT

The aim of the paper was to evaluate the usefulness of the Austrian Business Cycle Theory (ABCT) in explaining the changes in the wage structure occurring during different phases of the business cycle. Research methods applied are consistent with the methodological viewpoint of the Austrian School of Economics (ASE), using a mix of deductive reasoning and statistical analysis.

The analysis of data on wage developments in various sectors of the Lithuanian economy in a cyclical environment has allowed confirming the research hypothesis almost entirely. The study has demonstrated that from 2004 to 2013 during expansion and contraction phases the most dynamic change in wages occurred in sectors that were in the early stages of production, i.e. most distant from consumption, and were producing the most durable consumer durables.

Empirical verification of arguments formulated by the ASE is very rare. In global economic literature such studies of changes in the labour market during cyclical fluctuations are scarce. This study fills this gap by confronting the ASE theory with wage changes in a real-life economy.

Keywords: wages, labour market, business cycle, Austrian School of Economics, credit expansion, structure of production

JEL Classification Codes: E14, E32, E51, J01, J31
}

\footnotetext{
1 ORCID 0000-0002-3133-6880
} 


\section{Introduction}

Changes in the labour market are closely and systematically tracked and analysed in periods of accelerated economic expansion as well as, and perhaps especially, during contractions. Wages are the key category of the labour market. Wages fulfil many functions (informational, remunerative, motivational, and other social functions, as well as allowing for cost calculation) that are crucial for efficient market operation and for the well-being of employees and their families. In a free market economy wages are primarily used by market participants on both sides of the labour market as key indicators of what action they should take in order to maximize their gains. This leads to changes in employment level and structure. One of the characteristics of the modern economy is that wages are subject to cyclical fluctuations, the cause of which is still debated by economists [Kaletsky, 2010]. Therefore, wage growth (or wage dynamics) within the phases of the business cycle has an important role in theories of different economic schools. One of these schools is the Austrian School of Economics (ASE). The Austrian explanation of the causes of the business cycle differs from that of mainstream schools. The ASE suggests an alternative approach to the analysis of wages.

The aim of the study is to evaluate the use of the Austrian Business Cycle Theory (ABCT) in explaining the changes occurring in the wage structure in different phases of the business cycle. This aim will be realised by verifying a hypothesis implied by the ABCT. The hypothesis states that the expansionary lending policy of the banking system in a (national) economy causes specific changes in relative wages in the economy. According to the ABCT, during the economic expansion wages in sectors furthest from consumers increase in relation to wages in the industries producing consumer goods. During the recession the process works in the opposite direction.

The analyses and evaluation of the application of the ABCT conducted in this paper are the result of a research fellowship acquired in 2016 in Darbo Rinkos Tyrimų Institutas Lietuvos Socialinių Tyrimų Centro (Labour Market Research Institute of Lithuanian Social Research Centre in Vilnius). The objectives of the fellowship were to get acquainted with the work and achievements of fellow scientists working for the Institute, and to conduct empirical research on the changes in the Lithuanian labour market occurring in the conditions of cyclical fluctuations in the economy.

\section{Wages and business cycle in theories of mainstream economics}

Changes in economic conditions impact the labour market through adjustment processes. Economic literature discusses several such adjustments channels, one of which are changes in real wages [Smith, 2003, Cahuc, Zylberberg, 2004]. According to one of the "stylized facts", 
the real wage is procyclical, although only slightly so [Abel, Bernanke, 1992]. Wages, as well as a bulk of other costs, are also sticky in relation to changes in production.

Among modern mainstream schools of economics that mainly use aggregates and averages in their analyses, there is no consensus in regard to how the (real) wages behave during cyclical changes in production. The New Classical Economics (NCE), Real Business Cycle School (RBCS) and New Keynesian School (NKS) - i.e. schools that base their theories on the rational expectations hypothesis - explain the relation in a completely different manner [Snowdon, Vane, 2005].

The NCE economists analyse changes in the economy on the assumption that the markets always clear. Thus, they assume full flexibility of prices and wages. This is a continuation of the neoclassical school approach. Such assumptions make the analysis of functioning of the free-market labour market largely an abstract one. Although it has its uses, its explanatory power regarding economic changes that occur in the reality of the modern world is highly limited. The assumption that current real-life wages are actually fully flexible, up and down, is hardly acceptable. According to the NCE theory, the equilibrium in the labour market is determined by more forceful adjustments of wage rates, and weaker quantitative adjustments of the number of workplaces. Thus, real wages fluctuate according to the direction of changes in production occurring in subsequent phases of the business cycle [Barro, Grossman, 2008].

The RBCS maintains the same basic assumptions of the NCE. The RBCS makes some additional assumptions though, including the intertemporal substitution of work hypothesis. According to the hypothesis, households increase their labour supply by shifting it from the future when the real wages in the present are temporarily high, and the households decrease their labour supply when the wages are temporarily low. This means that slight transient changes in real wages cause large backlash reactions in labour supply [Arnold, 2002]. However, the expectations of a permanently higher future wage reduce the present labour supply. The RBCS explains changes in production and wages as the result of emerging supply shocks, mainly technology shocks. The School argues that the real wage varies in accordance with the business cycle phases. Emerging technological innovations encourage businesses to increase their investments and demand for labour. The production function shifts to the right. The effect on the economy is a decline of the average price of consumer goods and services. This decline is a factor conducive to the growth of real wages during the expansion phase of the cycle. Growing demand for labour is the second factor. The RBCS economists argue that the reaction of labour supply, and in effect the change in the wage rate, depends on how market participants will interpret the supply shock: whether it is temporary or permanent. Herein lies a serious problem: how market participants are to determine the nature of the shock on its onset? Obviously, its nature becomes manifested only after it ends.

The NKS denies full flexibility of wages and prices. The School focuses on finding the microeconomic foundations of price and wage rigidity [Blanchard, Gala, 2010]. Therefore, according to the NKS, during business cycles changes in labour demand lead to large changes in employment and small changes in wage rates. Some economists focus on explaining nominal 
rigidity, others on explaining real rigidity. The main argument for nominal wage rigidity is the existence of long-term wage contracts. Both employers and employees are interested in signing these contracts as they (1) reduce the transaction costs of bargaining; (2) reduce the risk of failure of negotiations; and (3) give time to examine the behaviour of other firms.

According to Ball and Romer [1990], the nominal rigidity can arise from a combination of real rigidities and small nominal frictions. That is why modern NKS economists focus on the theoretical explanation of real wage rigidity. The most advanced is the concept of efficiency wages. In the efficiency wages framework there are several models, e.g. of negative selection, of staff turnover frequency, and of shirking and non-shirking that also incorporates sociological aspects of labour. These models aim at demonstrating that the efficiency of work depends on the real wage rates. Firms are interested in maintaining high and stable wages in order to encourage high productivity among their employees. Modern research explains the impact of wages on productivity by incentives and processes of selection applied by firms. In contrast, the insider-outsider theory of employment emphasizes the role of organised employees (contemporarily mostly through labour unions). These employees' power results from the cost of staff turnover. Well-situated employees may refuse to cooperate with new ones, and may harass them. Therefore, they have a tool that they can use to indirectly influence the wage policy of their employers. The insider-outsider theory attempts to demonstrate that better organisation of the employees tends to cause real wages to be higher and more stable.

At present, an important factor in theories of each of these schools - a factor that impacts company wage policy significantly - is state intervention. It affects the labour market directly by use of minimum wage laws or income taxes or by creating conditions for hiring and firing employees. Also of great importance is the indirect influence of government, such as business cycle stabilization policy, state aid to individual industries, or the level of unemployment benefits and social benefits.

\section{Wages under the business cycle according to the theory of the Austrian School of Economics (ASE)}

The Austrian Business Cycle Theory (ABCT) was created by Mises [1912, 1949] and Hayek [1929, 1931], and recently developed by Skousen [1990], Garrison [2001], Huerta de Soto [2009], Salerno [2012], and others. It seems to be a relevant alternative to mainstream economic theories in analysing and explaining the processes occurring in the various phases of the business cycle. The ABCT is based on the realistic capital theory that explains the actual technical process of production of consumer goods. This process is in turn based on the market mechanism of the price system. The ABCT links changes in the overall economy with the behaviour of individuals. It also integrates processes occurring in the financial sector and in the real sector. Moreover, the ABCT integrates factors that influence fluctuations in the economy both on the side of demand and on the side of supply. The theory also explains the 
role of savings in economic processes. The ABCT also stresses the importance of entrepreneurs who, as creative individuals working in conditions of uncertainty, calculate subjectively in monetary terms, and seek to make profits.

According to the ASE, business cycles are characteristic to the modern banking system based on fiduciary money and the fractional reserve system. The ASE stresses that the main cause of cyclical fluctuations in the economy is the easy monetary policy of the central bank. The traditional - and to this day prevailing among Austrian economists - approach of Mises [1934] suggests that the expansion phase starts after the central bank decides to reduce its interest rates below the equilibrium (or market or natural or pure) interest rate. This equilibrium interest rate is defined as the price established on the free market by all buyers and sellers who trade current goods in exchange for future goods [Rothbard, 2007]. This interest rate balances voluntary savings with investments. However, lowering the interest rates is not the only way to establish an easy monetary policy. The key factor affecting business cycles are changes in the quantity of money [Hülsmann, 2011]. Increasing money supply is an essential precondition for credit expansion occurring in the banking system. Thus, changes in money supply are the main cause of changes occurring in the structure of production, while changes in the interest rate cause changes merely in the quantity of money. This is a reversed hierarchy in respect to the one used by modern central banks, where the interest rate is understood as the dominant factor [Woodford, 2011].

Thus, the Austrian view of the beginning of the cycle does not depart from the standpoint of most mainstream economic schools. When the central bank lowers its interest rates, the interest on loans of commercial banks soon follows, thus encouraging businesses to loan more money for investment, and also encouraging consumers to purchase consumer durables and non-durables. According to ASE economists, consumer durables, due to the long period of use, should be treated the same way as capital goods [Skousen, 1990]. That is why the vast majority of loans is treated as loans used for the purchase of capital goods. While mainstream economists focus only on the change in quantity of money, the Austrians additionally emphasise the point of entry of the additional money to the economy. This is called the Cantillon effect [Cantillon, 1755, Rothbard, 2006].

The newly created money creates the so-called forced savings, or in other words cash resources that do not result from the voluntary decisions of market participants to increase their savings [Hayek, 1975]. The initial increase in money demand in the expansion phase of the business cycle is not spread evenly across all sectors of the economy; rather than that, it is concentrated in particular industries. This fact is crucial for the ABCT, which is based on Böhm-Bawerk's [1891] capital theory. According to Menger [1871], there are two main categories of goods: goods of the first order (consumption or final goods), and goods of higher orders (intermediate or capital goods, farther from consumption); the latter are used to produce the former. Intermediate goods make up the temporal structure of production of consumption goods. The structure itself consists of stages of production arranged in the order corresponding to the technical process of production and sales of the final good. By necessity 
this production process unfolds in time, and can only be analysed in the temporal context. The structure of production, which in the real-life economy is very complex, is illustrated by a simplified diagram shown in Figure 1. Capital goods are heterogeneous. The division (perpendicular to the vertical axis) represents the distance from consumer goods. This is why some capital goods are farther away from consumption (as in the case of machinery) or closer to it (e.g. semi-manufactured products). By definition, the market value of capital goods is capital [Huerta de Soto, 2009].

\section{Figure 1. Structure of production diagram}

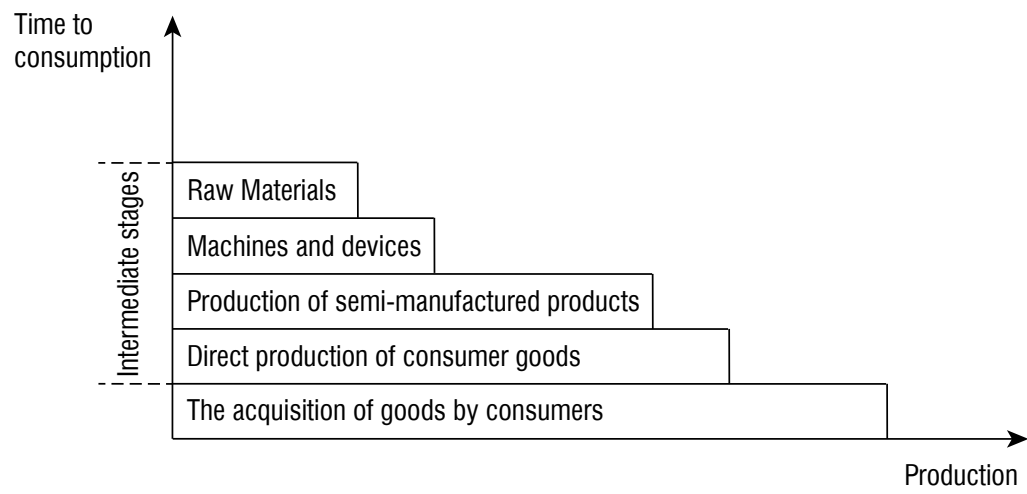

Source: the author's own work.

The capital accumulation is fundamental to the creation of capital. The accumulation is necessary in order to produce a larger amount of consumer goods using the same amount of primary factors (land and labour, i.e. the earliest stages of production possible). This can be done by adopting more sophisticated methods of production, or by increasing the number of stages of production. "That roundabout methods lead to greater results than direct methods is one of the most important and fundamental propositions in the whole theory of production." [Böhm-Bawerk, 1891, p. 20]. Switching to more capital-intensive methods results in lengthening the production time. It also delays the realisation of higher consumption.

Credit expansion by the banking system leads to changes in the structure of production, and also to changes in the price structure [Jędruchniewicz, 2013, 2015]. The wage structure is also altered. The new money allows businesses to use more capital-intensive production methods and to increase investment in the production of consumer durables [Salerno, 2001]. Thus, the widening and lengthening (deepening) of the production structure in the economy occurs (Figure 2). The initial production structure consists of four technical stages (the numbering increases for the stages farther from consumption). The monetary expansion is followed by the widening of the production structure. This means an increase in production at the currently existing stages (1-4). The farther the production stages from the consumer, the more rapid the increase in production. This is illustrated by the rightward shift in the $\mathrm{KP}_{1}$ curve of production. The $\mathrm{KP}_{1}$ curve represents annual production value at all the stages 
of production. Furthermore, the production structure in the economy may also lengthen. This lengthening process means that producers are adding new previously non-existent stages to the existing structure of production of consumer goods, e.g. by increasing funds for research, introducing new equipment, or modernising production. Figure 2 illustrates the formation of a new production pattern, now consisting of six steps (1-6). Summarily, the widening and lengthening of the structure of production is represented as the creation of the new production curve $\mathrm{KP}_{2}$.

\section{Figure 2. The structure of production and the growth of money supply}

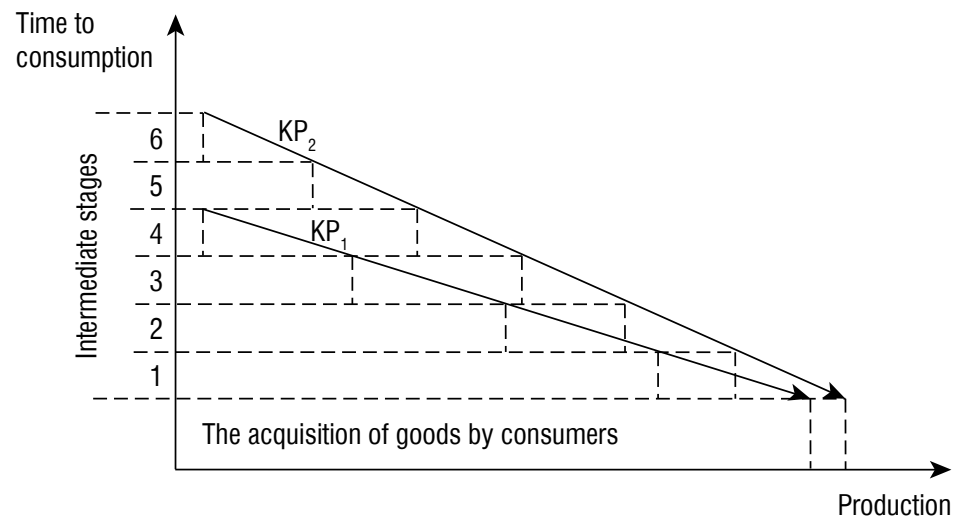

Source: the author's own study based on Skousen, 1990.

Because of the technical process of production of final goods, along with the long duration of use of consumer durables, at the onset of the business cycle the demand rises most dynamically in the early stages of the production structure, i.e. farthest from the consumer. In contrast, in the final stages of production the demand rise is minimal. Thus, Austrian economists emphasize that the cycle cannot be analysed only in macroeconomic terms, because global aggregates and averages obscure the real-life structure of processes occurring in individual sectors of the economy [Cochran, 2011]. In their view, analysis should be focused on relative categories, i.e. changes occurring in specific sectors in relation to changes in other sectors.

According to the ASE, during the business cycle different categories of wages (the same goes for production and prices) change at different rates. Wage dynamics in such a labour-intensive stage of production depends on how temporally remote it is from consumption, and on the durability of the final product. During the expansion phase wages rise most dynamically in sectors at the early stages of production. This results from insufficient supply and heterogeneity of workers, coupled with a significant increase in the demand for labour. Whereas sectors of immediate consumer goods production are characterised by the smallest changes in wages [Garrison, 2001]. Such changes in wage interrelations stemming from credit expansion may in reality be distorted by other factors that at any given time have a significant impact; among these factors are changes in buyer preferences, changes in exports and imports, the situation on international markets, or government interference. 
Credit expansion has lengthened the temporal structure of production. However, it does not lengthen the temporal structure of consumption. The intensification of consumer demand growth causes the production to shift to stages closer to consumption. Eventually, the decline in demand for capital goods initiates the contraction phase. Its main cause is the artificial lengthening of the temporal structure of production; this is founded on erroneous information and ignorance of the temporal structure of consumption in the expansion phase [Salerno, 2012]. The temporal structure of production in the economy is being shortened (shallowed). This involves removing some stages in the production of consumer goods. As the production structure in the economy shortens, it also narrows, i.e. the output falls in the remaining stages of production.

Figure 3. Wages changes during the recession (in \%)

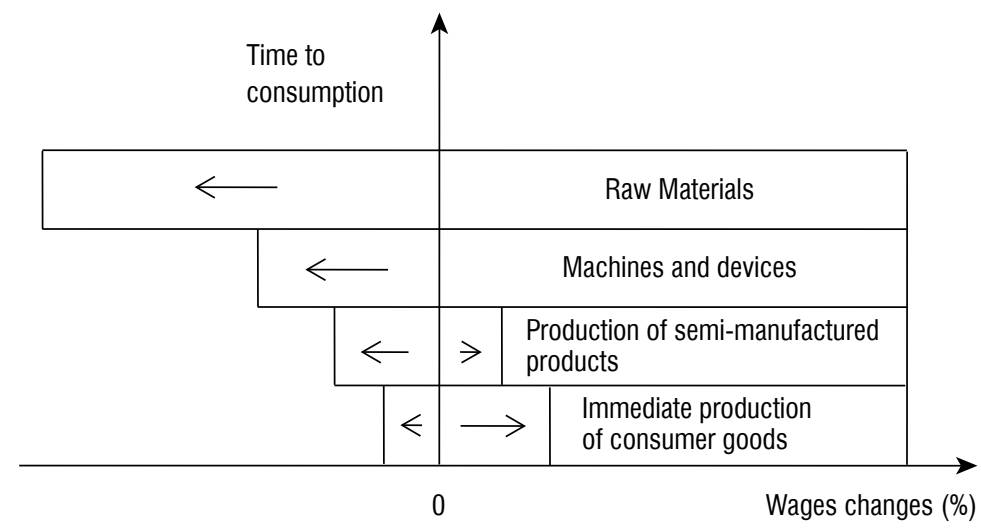

Source: the author's own work.

During the recession bad investments (or in other words malinvestments) are being removed from the structure of production in the economy. This removal consists of processes that are distressing for many firms and individuals. "The depression period, therefore, is the necessary recovery period." [Rothbard, 2008, pp. 1000-1001]. According to Austrian economists at that time changes in wages as well as in production and in prices are inverse to the changes occurring in the expansion phase (Figure 3). In the conventional version of the ABCT wages are falling in all sectors. The early stages of production structure are impacted the most, because the malinvestment in these sectors during the expansion was the most severe. The least affected are the wages in industries in stages closest to consumer goods. In the modern economy, in which expansionary economic policy is pursued more than often, wages in industries that are close to consumption may increase in absolute terms. 


\section{Empirical analysis of changes in wages in the Lithuanian economy}

\subsection{The research methodology and data}

The methodology of the Austrian School of Economics (ASE) is a vast departure from research methodology used by mainstream schools of economics. The roots of this departure lie in criticism of the possibility of applying the same methods in economic sciences and in natural sciences. The ASE indicates that the nature and object of research in both sciences differ radically (more on the methodological dualism in Mises, 1949 and Rothbard, 1992). Thus, economics should not apply research methods of natural sciences because: (1) human behaviour cannot be described by means of mathematical functions and stochastic correlations, but only through causal reasoning, because human beings are teleological, free-willed and thinking, having subjective knowledge, and acting purposely and creatively; and (2) there are grave methodological problems with measurement when applied to various economic categories [Huerta de Soto, 1998].

Austrian economists suggest that the methodology of theoretical economic research should only use deductive reasoning and verbal logic. This is consistent with the principle of Occam's Razor, as it strives best for the simplest description of scientific phenomena. However, this approach is in stark contrast to the prevailing mathematical formalism. Economists generally use extremely complex econometric models to determine economic laws and relationships. The ASE raises several criticisms against this methodology: (1) analysis and interpretation of data without a solid theory usually results in random statements; (2) the methodology analyses economic processes in terms of general equilibrium; (3) it also entertains unrealistic assumptions; (4) objective common measurement of individual utility is an impossibility; (5) in social reality there are no constant quantitative relationships between categories; (6) mainstream models often ignore the fact that sequential processes are temporal and can interrelate temporally; and (7) it is highly problematic, to say the least, to include all the relevant variables in mainstream models [Wisniewski, 2012, Rothbard, 1992, White, 1984].

However, the ASE economists have no such clear-cut position regarding the possibility of verifying economic hypotheses by use of numerical data. Most Austrian scholars deny this possibility. However, there is a group invoking Hayek's standpoint that verification of hypotheses in this manner confers a significant advantage. A negative verification with respect to the theory forces to look for possible errors in deductive reasoning and to identify the causes that have disrupted the tested relationship.

The research methodology adopted in the present research is consistent with the methodological position of the Austrian School. And in particular, it is consistent with the aforementioned standpoint of empirical testing of hypotheses (see Mulligan, 2006, Bismans, Mougeot, 2009, Luther, Cohen, 2014). The article, thus, combines deductive methodology with statistical 
analysis to determine the structural changes in wages in the environment of the business cycle. The indicators used in the article are only a numerical description of the phenomenon. They do not interpose into its picture, as do econometric models.

The research covers the period of 2004-2013. In the Lithuanian economy during this time there was a period of dynamic growth, of strong economic downturn, and then of moderate recovery. The period is sufficiently long to make the verification of the research hypothesis possible.

The data used in this paper originates from publications by (and websites of) Statistics Lithuania and Bank of Lithuania.

\subsection{Changes in GDP and in the total volume of loans}

The Lithuanian economy in the studied period of 2004-2013 was undergoing dynamic changes. This period can be divided into three parts: (1) expansion (2004-2008), when it was one of the fastest growing economies in Europe; (2) contraction (2008-2010) with a nearly 15\% drop in production in 2009; and (3) recovery (2010-2013), when GDP growth was at moderate average rate of about $4 \%$ (Chart 1). To establish these phases analytically - in spite of the fact that the precise determination of duration of such phases is always arguable - annual changes in the real GDP were used (cf. Proskute, 2012). The trend was defined as the mean value of annual changes in GDP over 10 years.

\section{Chart 1. Annual changes in real GDP in Lithuania (in \%)}

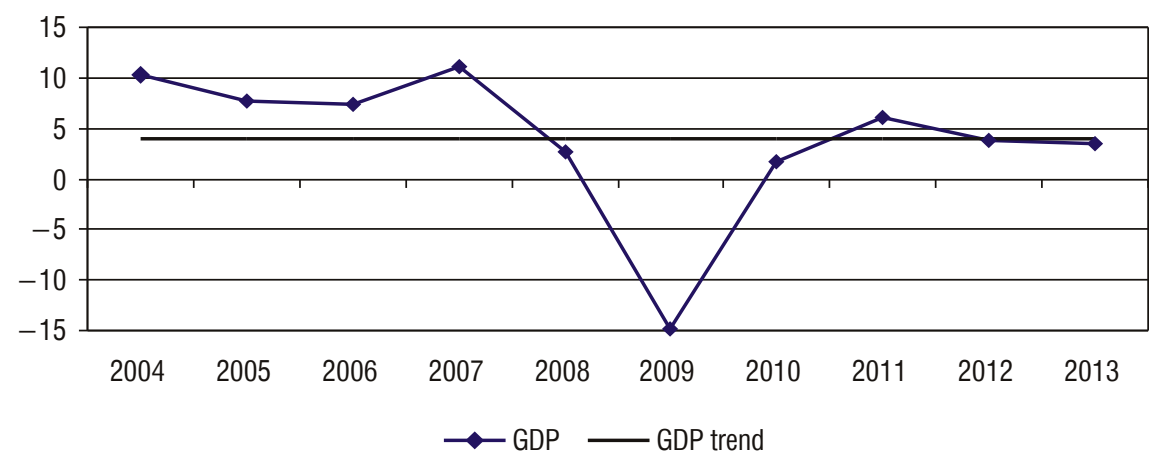

Source: Gross domestic product by production, by expenditure, by income approach, 1995-2016 (ESA 2010), http://osp.stat.gov.lt/ en/temines-lenteles39 [retrieved: 9 December 2016].

According to the Austrian Business Cycle Theory (ABCT), changes in the total volume of loans are the most important factor in regard to changes in the structure of production, prices, and wages. There is a causal link between credit expansion and development of the expansion phase of the business cycle. Theories of other schools in economics also seem to confirm this observation [Bernanke, Gertler, Gilchrist, 1999]. This link was patently visible in the 
Lithuanian economy. The expansion phase (2004-2008) resulted from a remarkably dynamic growth in the volume of lending to non-financial enterprises and to households (Chart 2).

The monetary policy of the Bank of Lithuania in the analysed period of 2004-2013 was based on the fixed exchange rate strategy. Money and credit supply were disconnected from the Bank and depended mainly on exogenous factors. The main factor here since 2001 has been the expansionary monetary policy of the European Central Bank, and that of the central banks of Nordic countries. A large influx of financial assets to Lithuania caused by the increased activity of foreign banks in the absence of exchange rate risk was the main cause of the growth in lending.

\section{Chart 2. Borrowing growth rate $(y / y$, in \%)}

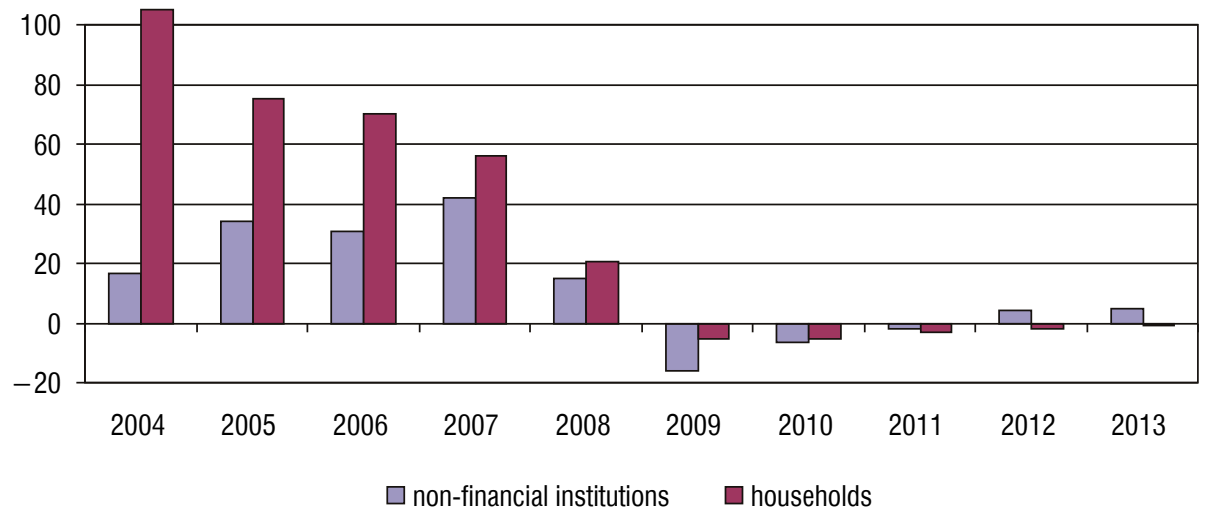

Source: the author's own calculations based on www.lb.lt/lietuvos_finansines_saskaitos [retrieved: 9 December 2016].

\subsection{Characteristics of the labour market in Lithuania}

Because of the size of the country, the Lithuanian labour market was and still is relatively small. In the analysed period the peak in employment was in 2004, and the trough in employment was observed in 2013 (Table 1). In 2013 the level of employment fell even below the trough in 2009, the year of the largest decline in the domestic product. This was primarily due to a large emigration of mostly young Lithuanian nationals, who were leaving predominantly during and after the economic crisis [Gruzevskis, 2003, Wolkonowski, 2014]. This conclusion can be supported by the growth in the employment rate in 2013 in comparison with 2004 and 2009 , accompanied by a simultaneous decrease in the total number of employees. In 2013 the labour force fell, even though the total number of unemployed decreased.

In the same year most labour market participants in the Lithuanian economy were employed in wholesale and retail trade, and repair of motor vehicles and motorcycles industry (227.5 thousand). 199.5 thousand workers were employed in the industrial sector, 125.8 thousand in education, and 108.9 thousand in the agriculture, forestry and fishing sector. Almost 100 thousand employees worked in the construction and transport sectors [Darbo rinkos..., 2014]. In 2004 the structure was similar. 
Table 1. Lithuanian labour market in 2004-2013

\begin{tabular}{|c|c|c|c|}
\hline Category & 2004 & 2009 & 2013 \\
\hline Employment (thousands) & 1436.3 & 1317.4 & 1292.8 \\
\hline $\begin{array}{l}\text { Employment rate (\%) } \\
\text { Men } \\
\text { Women }\end{array}$ & $\begin{array}{l}61.1 \\
64.6 \\
57.8\end{array}$ & $\begin{array}{l}59.9 \\
59.3 \\
60.4\end{array}$ & $\begin{array}{l}63.7 \\
64.7 \\
62.8\end{array}$ \\
\hline Unemployment (thousands) & 184.4 & 210.6 & 172.5 \\
\hline $\begin{array}{l}\text { Unemployment rate (\%) } \\
\text { Men } \\
\text { Women }\end{array}$ & $\begin{array}{l}11.4 \\
11.0 \\
11.8\end{array}$ & $\begin{array}{l}13.8 \\
17.1 \\
10.5\end{array}$ & $\begin{array}{l}11.8 \\
13.1 \\
10.5\end{array}$ \\
\hline $\begin{array}{l}\text { Average gross monthly earnings (litas, LTL) } \\
\text { Public sector } \\
\text { Private sector }\end{array}$ & $\begin{array}{l}1149.3 \\
1271.3 \\
1069.6\end{array}$ & $\begin{array}{l}2056.0 \\
2285.6 \\
1915.5\end{array}$ & $\begin{array}{l}2231.7 \\
2394.3 \\
2144.7\end{array}$ \\
\hline
\end{tabular}

Source: Darbo jèga, užimtumas ir nedarbas 2000-2005, Lietuvos statistikos departamentas 2006, Darbo statistikos metraštis 2005, Lietuvos statistikos departamentas 2006, Darbo rinkos metraštis 2013, Lietuvos statistikos departamentas 2014.

The unemployment rate in 2004-2013 in Lithuania always exceeded the average in the European Union (UE). The highest levels were reached during the economic crisis. This is a common phenomenon, as all major economic schools agree. In 2009 the unemployment rate for men significantly increased while, interestingly, it declined for women. According to the ASE theory, an increase in the rate for men was caused by the rapid reduction of production in sectors particularly vulnerable to the crisis, e.g. in the building sector. At the same time, the decline in the rate for women was likely caused by a large withdrawal from the working population.

The Lithuanian economy is less developed than most EU economies. Thus, in the analysed period the average wage in Lithuania was lower than there. However, in ten years it increased significantly in spite of the deep crisis (Table 1). In 2013 the average gross monthly earnings equalled approximately 550 Euros. Throughout the period, the average wage in the public sector was higher than in the private sector. This shows a strong influence of the public sector on governmental decisions regarding the distribution of tax funds.

\subsection{Changes in wages in various sectors of the Lithuanian economy}

Wages in Lithuania were analysed by many researchers in a number of ways. Most publications focused on the analysis of the factors influencing changes in wages, and especially the role of the minimum wage [Karpuskiene, 2011, Kasnauskiene, Seskaite, 2012, Bartkus, 2016]. Other studies discussed wage differentiation between Lithuania and other countries [Sileika et al., 2010, Ziogelyte, 2011]. Only a small number of publications focused on the issue discussed by this paper: namely, the relation between wage growth and business cycles [Racickas, Vasiliauskaite, 2010, Masso, Krillo, 2011]. However, we found no indications of the existence of publications focusing on the empirical analysis of this issue in light of the ASE theory not only in regard to the case of the Lithuanian economy, but also in regard to other countries. 
Research carried out by mainstream schools and focusing on the changes in wages predominantly uses the average wage in the entire economy. Austrian economists suggest that relying solely on aggregate and average values results in leaving out a lot of important information relevant for business cycles, as these values ignore changes in wages in specific sectors of the economy. The ASE maintains that this approach to business cycle research is incorrect, and it should include the relative changes in economic categories (see Garrison, 2001).

According to the ABCT, during the economic expansion the increase in wages should be most rapid in the sectors that are in the stages furthest from consumption and that produce the most durable consumer durables; on the other hand, the increase in wages should be most sluggish in the sectors that are closest to consumer goods and that produce consumer durables of low durability. During the recession the process should work in the opposite direction. In order to verify the hypothesis posed in the introduction to this paper it is necessary to demarcate categories comprising the structure of production of consumer goods. Processes occurring in the economy are always complex. This makes it impossible to demarcate categories that would represent these processes in an incontestable manner. Furthermore, the use of statistical data collected using the methodology of mainstream economics is inadequate in regard to the needs of the Austrian theory that uses the language of disaggregated data and production stages. This poses the greatest difficulty in the empirical research based on the ASE theory. Bearing these problems in mind, the categories were demarcated in such a way as to best preserve the logic of the temporal structure of production.

The first of such profiles of the structure of production, which will be used to examine the changes in gross wages, is based on a relatively general categorisation of the sectors of the Lithuanian economy: (1) mining and quarrying; (2) manufacturing; (3) water supply, sewerage, waste management, and remediation activities. These are characterised by varying degrees of remoteness from the consumer, and thus represent different stages of final goods production.

Chart 3. Annual wage rates in 2004-2013 (previous year $=100$ )

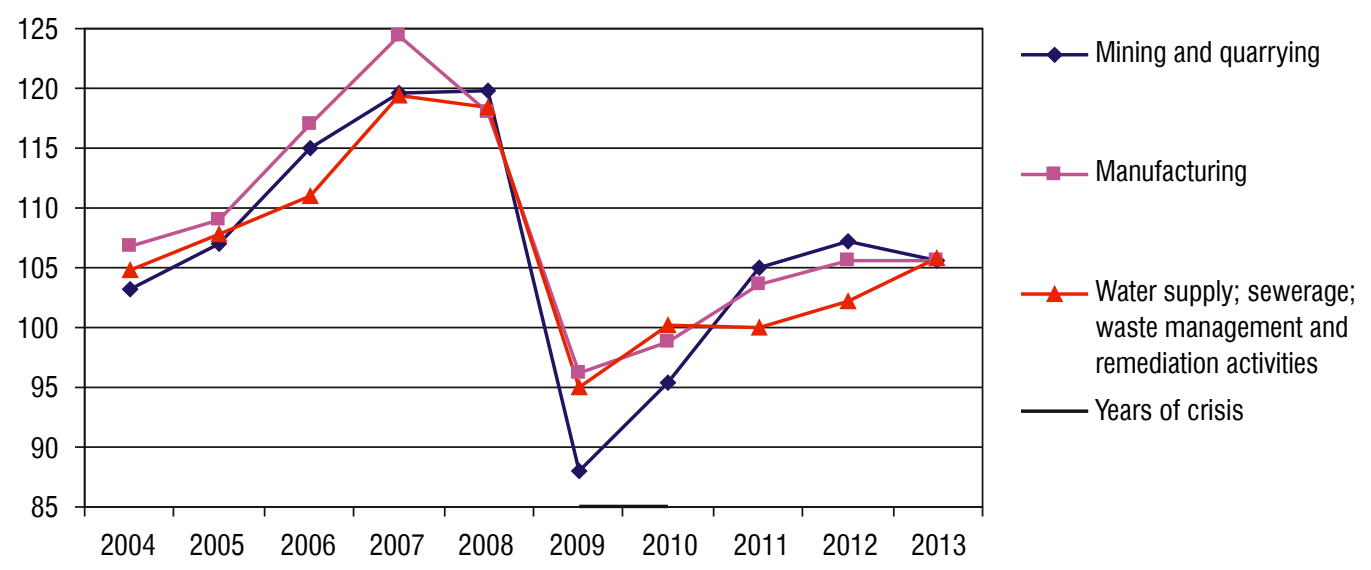

Source: the author's own study based on Darbo statistikos metraštis 2004-2010, Lietuvos statistikos departamentas 2005-2011, Darbo rinkos metraštis 2011-2013, Lietuvos statistikos departamentas 2012-2014. 
The analysis of annual gross wage changes in the selected sectors shows that the changes were consistent with the phases of the business cycle in the Lithuanian economy (Chart 3 ). Variability in wages during cyclical fluctuations plays a major role according to the Austrian theory. The wages in mining and quarrying varied most rapidly in 2004-2013. Standard deviation was 9.96 percentage points (pp). The wages in manufacturing showed lesser variability of $8.87 \mathrm{pp}$, and the lowest variability of $7.97 \mathrm{pp}$ was observed in water supply, sewerage, waste management, and remediation activities. Such a distribution of variability is consistent with the ASE theory.

Table 2. Wage changes by sectors during particular periods (in \%)

\begin{tabular}{|l|c|c|c|}
\hline \multicolumn{1}{|c|}{ Category } & $\begin{array}{c}\text { Expansion } \\
(2004-2008)\end{array}$ & $\begin{array}{c}\text { Recession } \\
(2009-2010)\end{array}$ & $\begin{array}{c}\text { Recovery } \\
(2011-2013)\end{array}$ \\
\hline Mining and quarrying & 81.8 & -15.9 & 18.8 \\
\hline Manufacturing & 100.3 & -5.0 & 15.5 \\
\hline $\begin{array}{l}\text { Water supply, sewerage, waste management, } \\
\text { and remediation activities }\end{array}$ & 77.7 & -4.8 & 8.1 \\
\hline
\end{tabular}

Source: the author's own calculations based on the data from Chart 3.

Austrian economists consider the relative changes in wages in particular sectors to be of crucial importance. The wage changes during the entire phases of the business cycle shown in Table 2 largely confirmed the claims of ASE economists that salaries in the sectors furthest from the consumer should be changing more rapidly relative to wages in the consumer goods sectors. During the expansion phase in Lithuania the wages increased the least in the water supply, sewerage, waste management, and remediation activities sector, and the most rapid increase occurred in manufacturing. The former increase is consistent with the ABCT, while the latter is not, because it is larger than the increase in the wages in the sector most distant from the consumer, i.e. the mining and quarrying sector. Moreover, the manufacturing sector consists of many industries, a number of which produce consumer goods. Potentially this can be explained by an improvement in the financial standing of firms in the manufacturing sector that results from the significant increase in exports of their production to the EU. This was a period of strong economic growth in Europe and of the Lithuania's accession to the EU. The latter resulted in the abolishment of restrictions on foreign trade between Lithuania and the EU.

During the depression and recovery phases the change in the wage structure was completely consistent with the ABCT (Table 2). Wage changes in the mining and quarrying sector were the most rapid, while the least rapid wage changes occurred in the water supply, sewerage, waste management, and remediation activities sector. During the recession there is a tendency in the economy to eliminate unprofitable business ventures from the structure of production. In contrast, during the recovery phase the increasing levels of lending to businesses cause more rapid changes in the early stages of the production structure.

The second profile of the structure of production is based on a more specific categorisation. We will use industries in the manufacturing sector that represent stages of production 
differentiated by their proximity to consumption: (1) manufacture of base metals and fabricated metal products, except machinery and equipment; (2) manufacture of wood and paper products, and printing; (3) manufacture of food products, beverages and tobacco. The study focuses only on two of the phases due to the availability of data on certain categories.

Chart 4. Annual wage rates by industries in 2004-2010 (previous year $=100$ )
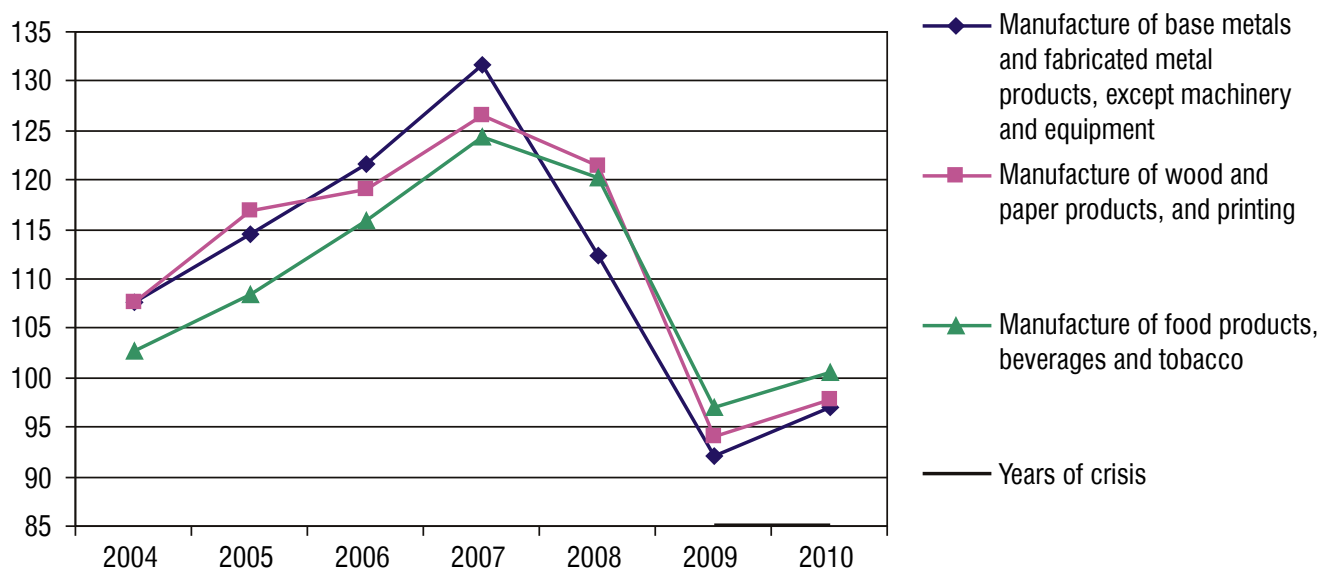

Source: the author's own study based on Darbo statistikos metraštis 2004-2010, Lietuvos statistikos departamentas 2005-2011.

The wage dynamics in branches of the manufacturing sector was once again in line with the business cycle phases (Chart 4). However, a clear drop in the pace of wage growth can be seen in 2008. Then, in the second half of the year, the crisis was already becoming more and more visible. In the analysed period the variability of wages in particular industries was consistent with the ABCT. The standard deviation of wages was the highest in the manufacture of base metals and fabricated metal products, except machinery and equipment industry (13.71 pp), and the lowest in the manufacture of food products, beverages and tobacco industry (10.45 pp).

Table 3. Wage changes by industries in different periods (in \%)

\begin{tabular}{|l|c|c|c|}
\hline \multicolumn{1}{|c|}{ Category } & $\begin{array}{c}\text { Expansion } \\
(2004-2008)\end{array}$ & $\begin{array}{c}\text { Expansion } \\
\text { (No 2008) }\end{array}$ & $\begin{array}{c}\text { Recession } \\
(2009-2010)\end{array}$ \\
\hline $\begin{array}{l}\text { Manufacture of base metals and fabricated } \\
\text { metal products, except machinery and } \\
\text { equipment }\end{array}$ & 122.4 & 97.8 & -10.8 \\
\hline $\begin{array}{l}\text { Manufacture of wood and paper products, } \\
\text { and printing }\end{array}$ & 130.0 & 89.3 & -8.1 \\
\hline $\begin{array}{l}\text { Manufacture of food products, beverages and } \\
\text { tobacco }\end{array}$ & 93.1 & 60.7 & -2.4 \\
\hline
\end{tabular}

Source: the author's own calculations based on the data from Chart 4 .

The analysis of wage changes during the expansion and contraction phases in the Lithuanian economy confirms the views of Austrian economists regarding changes in relative wages (Table 3). By changing the length and width of the structure of production, the dynamic credit 
growth during the expansion phase seem to have caused the lowest increase in wages in the manufacture of food products, beverages and tobacco industry, i.e. the industry producing directly for consumers. During the recession, wages in this particular industry declined the least.

In 2004-2008, the greatest wage growth occurred in the manufacture of wood and paper products, and printing industry. According to the ABCT, such an increase should occur in the manufacture of base metals industry instead. However, when we take into account only the expansion phase during 2004-2007, then the relative wage changes confirm the standpoint of ASE economists. In 2008 the recession began. It appeared most immediately in the industries that were most remote from the consumer. The data from Chart 4 shows that in 2008 the wage growth was at its lowest in the manufacture of base metals and fabricated metal products, except machinery and equipment industry.

Unlike mainstream schools, the ASE stresses that the problem of durability of goods is very important for economic processes [Skousen, 1990, Rothbard, 2007]. The last profile of the structure of production is based on sectors selected on the basis of the differences between durability (i.e. duration of the ability to yield utility) of goods produced in these sectors: (1) construction; (2) wholesale and retail trade, repair of motor vehicles and motorcycles, (3) electricity, gas, steam and air conditioning supply.

\section{Chart 5. Annual wage rates (previous year $=100$ )}

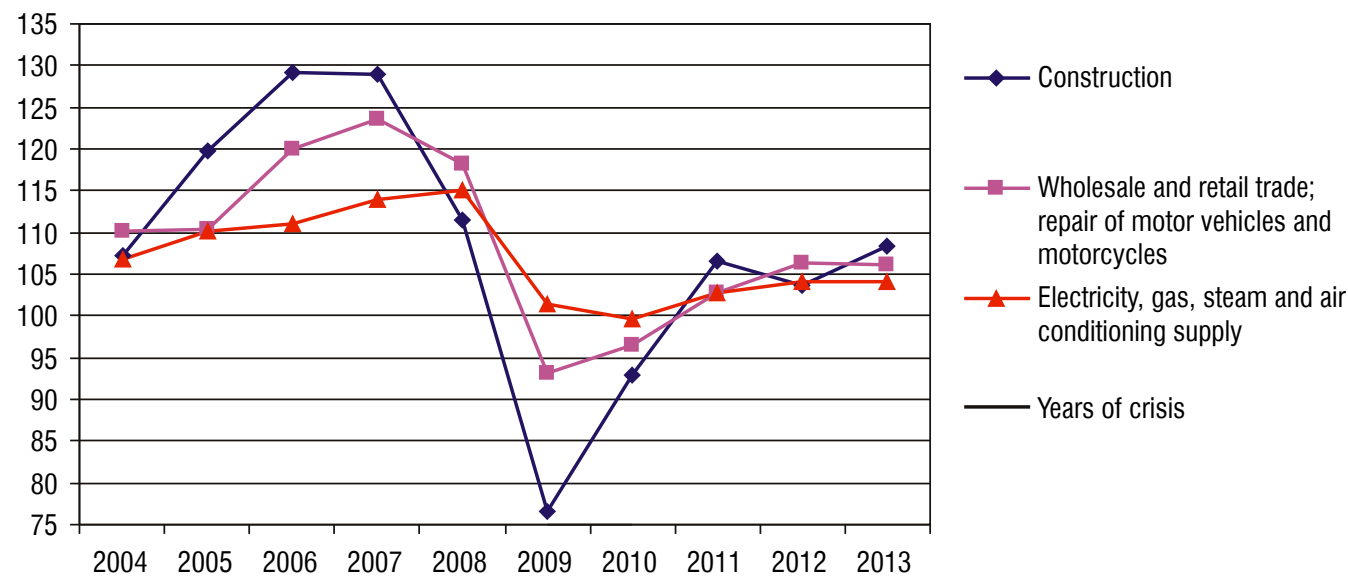

Source: the author's own study based on Darbo statistikos metraštis 2004-2010, Lietuvos statistikos departamentas 2005-2011, Darbo rinkos metraštis 2011-2013, Lietuvos statistikos departamentas 2012-2014.

In 2004-2013, i.e. in the period of expansion, recession and recovery, the variability of wages in sectors producing goods of varied durability differed significantly (Chart 5). The highest variability of wages occurred in the construction sector. Standard deviation was $15.89 \mathrm{pp}$. Meanwhile, the lowest variability occurred in the electricity, gas, steam and air conditioning supply sector. Standard deviation was $5.35 \mathrm{pp}$. This is consistent with the ABCT. According to the ABCT, sectors that produce highly durable goods should be similar in this regard to the sectors in the early stages of the production structure, i.e. they should manifest 
the highest variability during the business cycle. In contrast, sectors that produce goods that are consumed quickly should behave as sectors most immediate to consumption, and as such should be quite stable.

Table 4. Wage developments during the business cycle phases (in \%)

\begin{tabular}{|l|c|c|c|}
\hline \multicolumn{1}{|c|}{ Category } & $\begin{array}{c}\text { Expansion } \\
(2004-2008)\end{array}$ & $\begin{array}{c}\text { Recession } \\
(2009-2010)\end{array}$ & $\begin{array}{c}\text { Recovery } \\
(2011-2013)\end{array}$ \\
\hline Construction & 138.5 & -28.9 & 19.8 \\
\hline $\begin{array}{l}\text { Wholesale and retail trade; repair of motor vehicles } \\
\text { and motorcycles }\end{array}$ & 112.7 & -10.2 & 16.1 \\
\hline Electricity, gas, steam and air conditioning supply & 71.0 & 1.1 & 11.6 \\
\hline
\end{tabular}

Source: the author's own calculations based on the data from Chart 5.

The data in Table 4 that shows wage developments in the selected sectors in particular phases of the business cycle in Lithuania also fully confirms the theory of Austrian economists. During the phases of economic expansion (2004-2008) and recovery (2011-2013) the increases in wage rates were the highest in the construction sector, i.e. the sector producing most durable goods. At the same time, in the electricity, gas, steam and air conditioning supply sector, i.e. the sector producing goods consumed quickly, wage rates increased the least. During the recession, the structure of the absolute values of wage growth was the same as in the phases of expansion. In the construction sector wages fell the most. During the recession the entire sector was forced to reduce its production volume the most, because of the relative disconnection between the expansion of its production, which was stimulated by lending, and the demand based on voluntary savings of (mainly) households.

\section{Summary}

Austrian economists suggest that the Austrian Business Cycle Theory (ABCT) is a fruitful alternative to the theories of economic mainstream schools in its analytical and explanatory power with respect to the processes occurring during the business cycle phases, because, as they argue, of its realistic theory of heterogeneous capital. According to the Austrian School of Economics (ASE), the main cause of business cycles is the credit expansion of commercial banks caused by the creation of money. The expansion affects not only the changes in production and prices, but also in wages. Relative changes are key in the analysis of wages. The wage growth in a sector during the business cycle depends on its proximity to consumption and the durability of goods produced there. During the expansion phase wages rise faster in sectors in the early stages of the production structure. At the same time, wages rise most sluggishly in sectors producing consumer goods.

The analysis of the data on sectoral wage developments in the Lithuanian economy during the business cycle has resulted in an almost completely positive verification of the research 
hypothesis posed in the introduction to this paper. This was accomplished by using a selection of sectors and industries forming three profiles of the structure of production of consumer goods. The study has shown that (1) in 2004-2013 the variability of wages in sectors and industries most remote from consumption (mining and quarrying; manufacture of base metals and fabricated metal products, except machinery and equipment), and producing the most durable consumer durables (construction) was the highest; (2) due to the credit expansion during the expansion phases wages in these sectors, with two exceptions in 2004-2008, grew most rapidly; (3) during the recession the decline in wages in these sectors and industries was always the most dynamic one.

The verification of the hypothesis fulfilled the intended aim of the study. The results of the study allow concluding that the ABCT adequately explains the changes in the wage structure occurring in specific phases of the business cycle. Focusing in the analysis on the data concerning the structure of production, as compared to the use of the average wage in the whole economy, allows for a better understanding of wage dynamics.

\section{References:}

1. Abel A., Bernanke B.S., 1992. Macroeconomics. New York: Addison Wesley.

2. Ball L., Romer D., 1990. Real Rigidities and the Non-Neutrality of Money. Review of Economic Studies 57(2), pp. 183-203.

3. Arnold L.G., 2002. Business Cycle Theory. Oxford: Oxford University Press.

4. Barro R.J., Grossman H., 2008. Money, employment, and inflation. Cambridge: Cambridge University Press.

5. Bartkus A., 2016. The minimum wage and the Lithuanian labour market. Economics of Transition 25(1), pp. 47-75.

6. Bernanke B.S., Gertler M., Gilchrist S., 1999. The Financial Accelerator in a Quantitative Busines Cycle Framework. In: J.B. Taylor, M. Woodford (Eds.). Handbook of Macroeconomics. Amsterdam: Elsevier.

7. Bismans F., Mougeot C., 2009. Austrian Business Cycle Theory: Empirical Evidence. Review of Austrian Economics 22(3), pp. 241-257.

8. Blanchard O., Gali J., 2010. Labor Markets and Monetary Policy: A New Keynesian Model with Unemployment. American Economic Journal: Macroeconomics 29(2), pp. 1-30.

9. Böhm-Bawerk E. von, 1891. The Positive Theory of Capital. London.

10. Cahuc P., Zylberberg A., 2004. Labour Economics. Cambridge-London: The MIT Press.

11. Cantillon R., 1755. Essai sur la nature du commerce en general. Holborn-London.

12. Cochran J.P., 2011. Hayek and the 21st Century Boom-Bust and Recession-Recovery, Quarterly Journal of Austrian Economics 14(3), pp. 263-287.

13. Darbo jèga, užimtumas ir nedarbas 2000-2005. 2006. Vilnius: Lietuvos statistikos departamentas.

14. Darbo rinkos metraštis 2011-2013. 2012-2014. Vilnius: Lietuvos statistikos departamentas. 
15. Darbo statistikos metraštis 2004-2010. 2005-2011. Vilnius: Lietuvos statistikos departamentas.

16. Garrison R.W., 2001. Time and Money. The Macroeconomics of Capital Structure. LondonNew York: Routledge.

17. Gross domestic product by production, by expenditure, by income approach, 1995-2016 (ESA 2010), http://osp.stat.gov.lt/en/temines-lenteles39 [accessed: 9 December 2016].

18. Gruzevskis B. 2003. Labour migration in Lithuania. Nordic unemployment insurance meeting. http://www.cere.gr/upload/Labour\%20Migration\%20in\%20Lithuania.pdf [accessed: 12 December 2016].

19. Hayek F.A. von, 1929. Geldtheorie und Konjunturtheorie. Wien/Leipzig: Hölder-Pichler-Tempsky.

20. Hayek F.A. von, 1931. Prices and Production. London: G. Routledge \& Sons.

21. Hayek F.A. von,1975. "Profits, Interest and Investment" and Other Essays on the Theory of Industrial Fluctuations, Clifton.

22. Huerta de Soto J., 1998. The Ongoing Ethodenstreit of the Austrian School. Journal des Economistes et des Etudes Humaines 8(1), pp. 75-113.

23. Huerta de Soto J., 2009. Money, Bank Credit, and Economic Cycles. Auburn: Ludwig von Mises Institute.

24. Hülsmann, G., 2011. The Structure of Production Reconsidered. http://ead.univangers.fr/ granem08/IMG/pdf/DT-GRANEM-09-34.pdf [accessed: 15 November 2016].

25. Jędruchniewicz A., 2013. Struktura cen w polskim cyklu gospodarczym. Faza wzrostu. Bank i Kredyt 44(1), pp. 99-118.

26. Jędruchniewicz A., 2015. Struktura cen w polskim cyklu gospodarczym. Faza spadku. Ekonomia. Rynek, Gospodarka, Społeczeństwo 40, pp. 59-83.

27. Kaletsky A., 2010. Capitalism 4.0. The Birth of a New Economy. London: Bloomsbury.

28. Karpuskiene, V., 2011. The impact of minimum wage on the labour market of Lithuania. Ekonomika 90(2), pp. 78-87.

29. Kasnauskiene G., Seskaite J., 2012. The Causes and the Economic Impact of Immigration: Empirical Evidence for Lithuania. International Journal of Social Sciences and Humanity Studies 4(1), pp. 139-148.

30. Luther W.J., Cohen M., 2014. An Empirical Analysis of the Austrian Business Cycle Theory. Atlantic Economic Journal 42, pp. 153-169.

31. Masso J., Krillo K., 2011. Labour Markets in the Baltic States During the Crisis of 2008-2009: The Effect on Different Labour Market Groups. Working Paper, University of Tartu, Faculty of Economics and Business Administration.

32. Menger C., 1871. Grundsätze der Volkswirtschaftslehre. Wien: Braunmüller.

33. Mises L. von, 1912. Theorie des Geldes und der Umlaufsmittel. München und Leipzig: Verlag von Duncker \& Humblot.

34. Mises L. von, 1934. The Theory of Money and Credit. London: Jonathan Cape.

35. Mises L. von, 1949. Human Action: A Treatise on Economics. New Haven: Yale University Press.

36. Mulligan R.F., 2006. An Empirical Examination of Austrian Business Cycle Theory. Quarterly Journal of Austrian Economics 9(2), pp. 69-93. 
37. Proskute A., 2012. Causes and Characteristics of Business Cycle in Lithuania: A Structural VAR Approach. Ekonomika 91(1), pp. 41-58.

38. Racickas E., Vasiliauskaite A., 2010. Global Fnancial Crisis and Its Impact on Lithuanian Economy. Economics \& Management 15, pp. 1006-17.

39. Rothbard M.N., 1992. The Present State of Austrian Economics, http://mises.org [accessed: 20 November 2016].

40. Rothbard M.N., 2006. Economic Thought Before Adam Smith: An Austrian Perspective on the History of Economic Thought. Volume I, Auburn: Ludwig von Mises Institute.

41. Rothbard M.N., 2007, 2008. Ekonomia wolnego rynku. t. 2, 3, Chicago-Warszawa: Fijorr Publishing.

42. Salerno J.T., 2001. Does the Concept of Secular Growth Have a Place in Capital-Based Macroeconomics? Quarterly Journal of Austrian Economics 4(3), pp. 43-61.

43. Salerno J.T., 2012. A Reformulation of Austrian Business Cycle Theory in Light of the Financial Crisis. Quarterly Journal of Austrian Economics 15(1), pp. 3-44.

44. Sileika A., Tamasauskiene Z., Barteliene N., 2010. Comparative analysis of wages and labour productivity in Lithuania and other EU (15) countries. Social Research 3(20), pp. 132-143.

45. Skousen M., 1990. The Structure of Production. New York: New York University Press.

46. Smith S., 2003. Labour Economics. London-New York: Routledge.

47. Snowdon B., Vane H., 2005. Modern Macroeconomics. Its Origins, Development and Current Stat. Cheltenham: Edward Elgar.

48. White L.H., 1984. The Methodology of the Austrian School Economists, Auburn: The Ludwig von Mises Institute.

49. Wisniewski J.B., 2012. Metodologia austriackiej szkoły ekonomii: obecny stan wiedzy. http:// mises.pl [accessed: 20 November 2016].

50. Woodford M., 2011. Interest and prices: Foundations of a theory of monetary policy. Princeton: Princeton University Press.

51. Wolkonowski J., 2014. Causes and Structure of Emigration of Lithuania Citizens in the Period between 2003 and 2013, Research Papers of Wrocław University of Economics 348, pp. 437-448.

52. www.lb.lt/lietuvos_finansines_saskaitos [accessed: 9 December 2016].

53. Ziogelyte L. 2011. Evaluation of Wage Differentiation in the Baltic States from the Regional Perspective, Taikomoji ekonomika: sisteminiai tyrimai 5(1), pp. 77-100. 